\title{
Induction of Bone Marrow Adult Mesenchymal Stem Cells into Functional Motor Neuron
}

\author{
Rafal H. Abdullah \\ Iraqi center for cancer and medical genetic \\ research/Al-mustanserya university \\ Baghdad -Iraq \\ rafal.hussam@iccmgr.org
}

\section{Shahlla M. Saleh}

Al-Nahrain University shehlaam2006@yahoo.com

\author{
Nahiyosefyaseen \\ Iraqi center for cancer and medical genetic \\ research/Al-mustanserya university \\ Baghdad -Iraq \\ nahiyaseen@iccmgr.org
}

\begin{abstract}
Ahmed MajeedAlshamary
Iraqi center for cancer and medical genetic research/Al-mustanserya university ahmed

alshammari@iccmgr.org
\end{abstract}

\begin{abstract}
Mesenchymal stem cell differentiation into motor neuron cell then elongation of cell axon represent promising way for repair spinal cord injury and motor neuron cell dysfunction in mammal, using collagen matrix for mimicking the normal tissue structure. Differentiation of mice bone marrow mesenchymal stem cell to motor neuron was induced by adding different growth factors including pre induction step using $1 \mathrm{mMmercapotoethanol}$ (BME) in 20\% FBS in minimum essential media and then $2 \mathrm{mM} \mathrm{BME}$ in free serum media for $2 \mathrm{~h}$ and induction step using $1 \mu \mathrm{M}$ Retinoic acid and $(0.1 \mathrm{ng} / \mathrm{ml})$ sonic hedgehog in free serum media for 4 days. Results revealed that the differentiation medium used was very efficient in directing the BM-MSCs to the motor neural cell, which immunocytochemically showed positive reactivity to specific motor neural markers for detection of motor neuron cells using immunocytochemicallike microtubule associated protein-2 antibodiesand acetylcholine transferase antibody. Motor neuron cell activity was assessed by measuring acetylcholine level in culture media during differentiation using high performance liquid chromatochraphy (HPLC). Results showed that thehighest level was $(75.0 \pm 0.57 \mathrm{pmm})$ in induction stage in comparison with levelinthe pre induction stage $(15.36 \pm 0.44 \mathrm{pmm})$ with significant differences $P \leq 0.05$. While BM-MCsproduce acetylcholine in low quantity (15.43 \pm 0.38$)$.
\end{abstract}

Elongation of motor neuron axon was induced by adding different concentrations (10, 20, 40, 80, and 160) nglml of nerve growth factor (NGF) to differentiation media. Results exhibited a significant increase in axon length $(1.93 \pm 0.185) \mathrm{mm}$ was noticed at a concentration $160 \mathrm{ng} /$ when a nerve growth factor was added to motor neuron differentiation media in the induction stage in addition to RA and SHH compared. Results showed a significant increase in axon length was observed $(0.83 \pm 0.145,0.86 \pm 0.145,1.30 \pm 0.10$ and $1.76 \pm 0.317 v s 0.43$ $\pm 0.145) \mathrm{mm}$ respectively in comparison with control when serial concentrations of NGF added to culture media $(10,20,40$ and 80$) \mathrm{ng} / \mathrm{ml}$ respectively.

In the second part of work: culturing MSCs in three- dimensional model using collagen matrix represent a useful method for induction MSCs differentiation into motor neuron cell and mimicking neural cell condition. The differentiation of MSC in matrix was studied immunocytochemicaly on the surface of matrix with MAP-2 and Chat antibody marker, showing positive results for motor neuron differentiation.

Keywords: mesenchymal stem cell, motor neuron, acetylcholine.

\section{INTRODUCTION}

Spinal cord injury is a lesion of traumatic nature result to disruption of nerve fiber bundles effect on the ascending sensory and descending motor information(Julio,et.al,2012) .Stem cell represents a promising way for treatment of this injury because self-renewal and their ability to become any cell in an organism like neuron and glia cell. Neuroprotective and axon regeneration promoting effects have also been credited to transplanted stem cells (Tewarieet al., 2009).

Mesenchymal stem cell treatment for spinal cord injury improves functional recovery and enhanced astrogliosis and levels of inflammatory cytokines in rats using balloon-induced spinal cord compression lesions. Transplantation of mesenchymal stem cells is limited by poor survival of the cells in the damaged nervous tissue (Ritfeld and Oudega , 2014; Cui et al., 2014). 
Motor neurons are specialized nerve cells in the brain and spinal cord that transmit the electrical signals to muscle and generate movement. There are two group of motor neuron, the upper motor neuron at the top of the brain in motor cortex and extended down in the spinal cord to connect the lower motor neurons which travel out of the spinal cord and connect the muscle (Talbot, 2008).

Microtubule associated protein 2 (MAP-2) and Acetyl choline transferaseare differentiation markers for motor neuron. High-performance liquid chromatography (is a technique in analytical chemistry used to separate the components in a mixture, to identify each component, and to quantify each component (Kupiec, 2004). Therefore Acetyle choline concentration detected in culture media which is a neurotransmitter at neuromuscular junctions responsible for synapses in the ganglia of the visceral motor system, and at a variety of sites within the central nervous system (Purves et al.,2001).

The development of 3D scaffolds, support structures or matrices that induce cells to form functional tissues, is one of the main object of tissue engineering and regenerative medicine research (Langer and Vacanti, 1993).

Collagen type I used to form three dimensional cell culture matrix composed of collagen fibres are able to support short- and long-term growth of various cell types, including cancer cell lines, endothelial cells, endometrial cells, hepatocytes, osteoblasts and fibroblasts and to sustain or even enhance cell differentiation, in vitro, 3-D culture systems have been successfully used in the investigation of complex biological processes, such as angiogenesis, wound healing, tumour invasion , metastasisand simulate cell-cell interactions, which take place in tissues under physiological and pathophysiological conditions (Themistocleouset al., 2004).

Mesenchymal stem cell differentiation into functionally active motor neuron cell using Retinoic acid and Sonic hedgehog growth factor then studying elongating capability of differentiated cell axon and mimicking the normal tissue structure by in collagen matrix .

\section{Material AND Methods}

\subsection{Mesenchymal Stem Cell Isolation}

Bone marrow mesenchymal stem cell isolated from thigh of Albino mice used ,in using flushing method was used by flush the bone marrow cells from bones using a $1 \mathrm{ml}$ syringe containing $1 \mathrm{ml}$ of growth culture media (MEM). freshly isolated whole bone marrow cells were resuspended in $5 \mathrm{ml}$ growth culture medium MEM supplemented with $20 \%$ FBS, $1 \%$ Ampicllin/Streptomycin in 37C (Soleimani, M.and Nadri,2009).when the cultures reached 80 - $100 \%$ confluence, the cells were suspended in culture at density $\left(>10^{6}\right.$ cells $\left./ \mathrm{ml}\right)$. the cell viability studied by using trypan blue dye which allows distinguishing between healthy cells with uncompromised membrane integrity (unstained) and dead ones (stained blue).The Immunocytochemistry analysis of MSCs was done by CD 105 CD90+, CD 34-, CD 44+ (Lin,et.al,2013).

\subsection{Differentiation of MSC into Motor Neuron Cell}

In motor neuron differentiation the 1 st passage of $\left(2 \times 10^{4}\right)$ of MSCs were used. The differentiation strategy involved two main steps (preinduction step) the cells were cultured in a MEM medium supplemented with 20\% FBS and $1 \mathrm{~m} \mathrm{MB}$ etamercaptoethanol (Santa Cruz biotechnology). After $24 \mathrm{~h}$ of incubation the media was discarded and MEM free serum media containing $2 \mathrm{mM}$ BME was added and incubated for $1 \mathrm{~h}$. Then media was discarded and cell washed with free serum media. At the second step (induction step) which lasted for four days MEM free serum media with $1 \mathrm{mM}$ retinoic acid(Santa Cruz biotechnology), 10ng/ml nerve growth factor(Santa Cruz biotechnology)and 0.1 $\mathrm{ng} / \mathrm{ml}$ sonic hedgehog (Santa Cruz biotechnology )were added and incubated at $37^{\circ} \mathrm{C}$ for 4 days. As a negative control, MSCs were cultured in medium without differentiation stimuli along with the differentiation experiments in the same conditions. Cells were cultured in a humidified atmosphere of $5 \% \mathrm{CO} 2$ and $95 \%$ air at $37^{\circ} \mathrm{C}$. Cultures were maintained by medium exchange every 2 days. The cell morphology was observed under inverted microscope according to modification method of (Hu and Zhang, 2009).

\subsection{Motor Neuron Detection by Immunocytochemisty}

After that the media was aspirated and the cell was fixed by $4 \%$ paraformaldehyde for $10 \mathrm{~min}$, incubated with $1 \%$ hydrogen peroxide for 10-15 minutes and wash with PBS for 5 min three 
times.Aliquot of $1.5 \%$ blocking serum was added to cell section for one. Cells sections were incubated with diluted acetyletransferase antibody at a ratio ( $1: 50 \mathrm{vol} / \mathrm{vol})$ overnight as production company instruction and diluted microtubule associated protein antibody at a ratio (1:100vol/vol $)$ for $1 \mathrm{~h}$ then washed. Cell sections were incubated for $30 \mathrm{~min}$ with $1.2 \mathrm{ml}$ biotinylated secondary antibody.A liquid of $650 \mu \mathrm{l}$ of $\mathrm{AB}$ enzyme reagent was added to cell section and washed two times with PBS for $2 \mathrm{~min}$. Three drops of peroxidase substrate was added to cells for 10min, or until desired stain intensity develops and washed. Hematoxylin stain was added to cell section for 5-10 seconds and immediately washed with distilled water. Finally 1-2drops of permanent mounting medium was added and examined by light microscopy at magnification powers 200X and 400X (Moral-Sanz, et.al. 2012).

\subsection{Scanning by Electron Microscope}

Scanning electron microscope solutions ( $4 \%$ gluteraldehyde). It was prepared by mixing $4 \mathrm{ml}$ of stock gluteraldehydewith $94 \mathrm{ml} \mathrm{D.W}$. .It was prepared by dissolving $1 \mathrm{mg}$ of osmium tetroxide in $10 \mathrm{ml}$ D.W., Thenstored in dark container at -20.The slides were washed by PB Sand fixed with gluteraldehyde $4 \%$ for $24 \mathrm{~h}$ at $4^{0} \mathrm{C}$ then Osmium solution was added for $2 \mathrm{~h}$ in dark. At the end of two hour, slides were washed with PBS two times. A serial dehydration for the sections were carried out started from $(50,70,95$, and 100) $\%$ for 30 min,dried and examined under the electron microscope (Eisenbach,2015).

\subsection{Motor Neuron Function Detection}

The activity of motor neuron detected using HPLC by estimation acetylcholine concentration in media at different period of differentiation.

The test was done in IbinSenaCenter /Ministry of higher education and scientific research, usingshimachzu lc-2012 AHT machine.

\section{- HPLC Conditions}

Standered Acetylcholine was prepared by dissolving $1 \mathrm{mg}$ acetylcholine chloride powder $>98 \%$ purity in $1 \mathrm{ml} \mathrm{D.W.}$

A column $250 * 4.6 \mathrm{~mm}$ colume 5 micron lava with Injection volume $0.7 \mathrm{ml} / \mathrm{min}$. Column temperature was $18{ }^{\circ} \mathrm{C}$, Detection wavelength: $210 \mathrm{~nm}$ and Mobile phase: Acetone, water methanol 80\%, 14\%, 6\%(Landgraf et .al,2010) .

Acetylcholine concentration was calculated according to this equation (Chen and Yun, 2009).

Concentration of compound $(\mathrm{ppm})=$ area of sample $\times$ conc. of standard

area of standard

\subsection{Assay of Elongating Moto Neuron Cell Axon}

Mesenchymal stem cell was cultured in five tissue culture flask at $37^{\circ} \mathrm{C}$ in $\mathrm{CO} 2$ incubator until monolayer formed. Media was discarded and pre induction media was added to each flask .At the end of pre induction time, the preinduction media was discarded and induction media containing different concentrations of nerve growth factor started from $10,20,40,80$ to160 ng/ml (Lentz,etal. 1999).

\subsection{Axon Length Measurement Program}

The axon length was measured using mini divi camera picture program measurement (Qiang et al., 2010; Olsson-Carter et al., 2010 and Cregg et al., 2010).

\subsection{Three Dimension Collagen Culture}

\subsubsection{Preparation of neutralized collagen solution}

Neutralized collagen solution was prepared by mixing 8 parts of chilled collagen solution to 1 part $0.01 \mathrm{M} \mathrm{NaOH}$ and 1 part $10 \mathrm{X}$ buffered serum free cell cultured medium. Then $\mathrm{pH}$ was adjusted to $7.4 \pm 0.2$ and poured on $3 \mathrm{D}$ seeding plate with 8 wells (the thickness of collagen gel should be $1-2 \mathrm{~mm}$ ) and incubated at $37{ }^{\circ} \mathrm{C}$ for $20 \mathrm{~min}$. The plate left over night to dry and rinsed with DDW to remove excess salt and to rehydrate collagen gel and used immediately or dried again and stored for weeks at 2-8 C as manufacturer instruction (Wuensch, et.al.2013). 


\subsection{Three Dimensional Culturing}

Mesenchymal stem cell was cultured on neutralized collagen seeding plate with 8 wells according to Artym and Matsumoto, (2010) with modification $6 \times 10^{6} \quad$ cell $20 \mathrm{ml}$ of $20 \%$ FCS culture media, then $400 \mu \mathrm{l}$ of cell suspension was added to each well of the neutralized collagen seeding plate and incubated in $\mathrm{CO} 2$ incubator at $37^{\circ} \mathrm{C}$ until monolayer formed. Every 2-3 day, slide media was aspirated carefully without contact to the collagen to prevent its shrinking or damage from the side wall of slide and new culture media added carefully. Motor neuron differentiation was induced as previous.

At the end of differentiation motor neuron detection by immunocytochemistry was carried out as mentioned above.

\section{Results}

\subsection{Motor Neuron Induction}

Mesenchymal stem cell have the ability to differentiated into neuron like cell and more specialized cell like motor neuron when using simple differentiation factors in practically short period of time not more than 5 days.

There are two stages of differentiation using monolayer of passage one MSCs, The first stage of differentiation, a pre induction stage for $24 \mathrm{~h}$ showed that the fibroblast like cell MSC cell membrane withdraw to the middle of the cell, extension became appear and the cell still viable with account 1.9 $\mathrm{X} 10^{6}$ and attached to the flask surface Figure (1). The media discarded and incubated for 1 hour in $2 \mathrm{mM} \beta$ ME of free serum MEM, the cell became more radical in shape, multi polar, and extension increased in number of viable count to about $1.40 \times 10^{6}$.
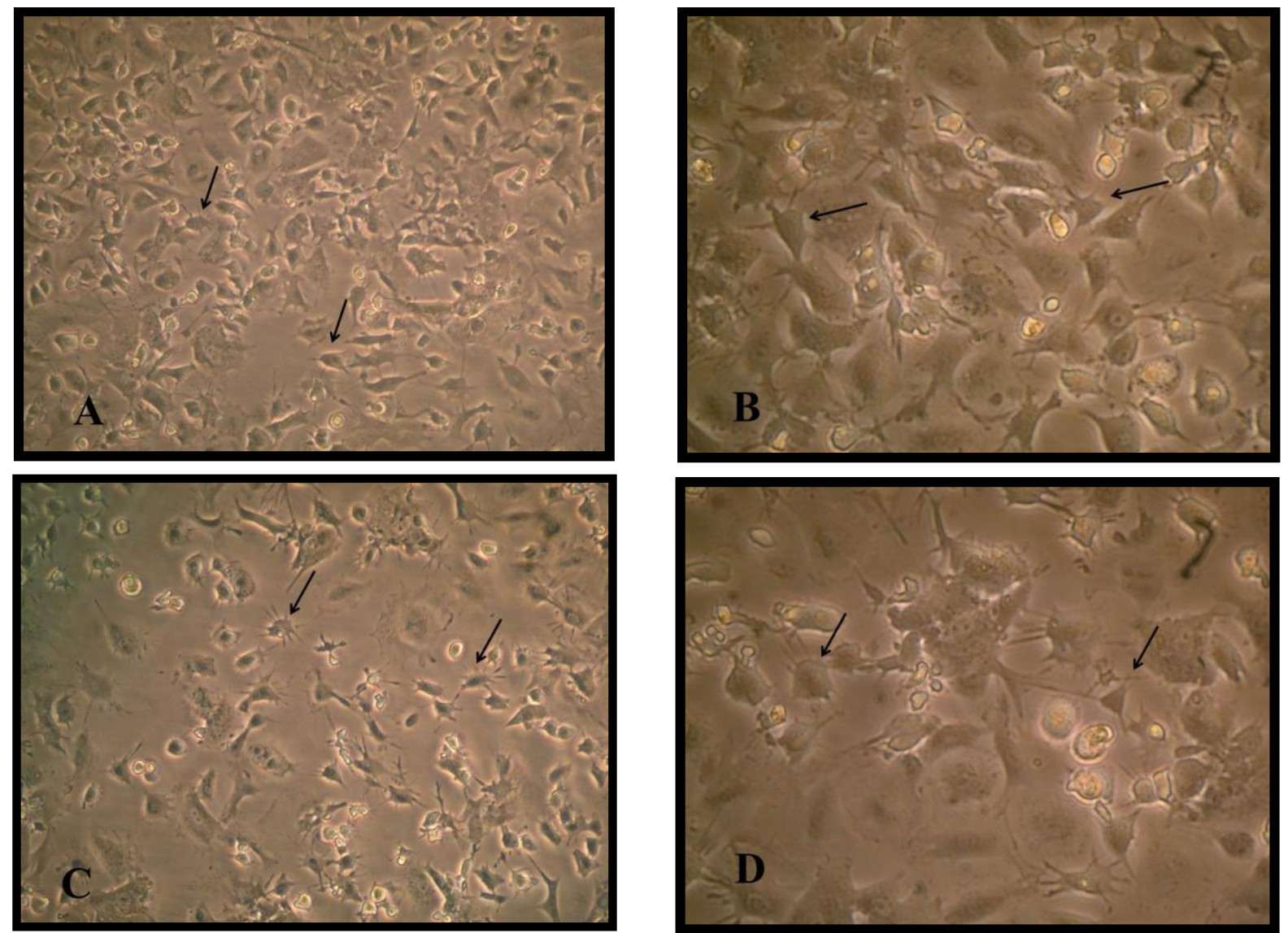

Figure1. BM-MSCs differentiation A and $\mathbf{B}$ pre induction stage after $24 \mathrm{~h}$ in $1 M$ BME in MEM 20\% FBS viewed by inverted microscope (10X10) (10X20) showed that the fibroblast like cell MSC cell membrane withdraw to the middle of the cell. $\mathbf{C}$ and $\mathbf{D}$ a pre induction stage after1hour in 2.mM $\beta$ ME of free serum MEM showed that the cell became more radical in shape and multi polar.

The second stage of differentiation was the induction stage in which used a combination of Retinoic acid and a Sonic hedgehog factors for just four days, cell body became typical like motor neuron cell, shiny nuclease and with the cell soma have many dendrites and long axon like structure ended with 
small extensions. The MSCs under three thousand increase size using scanning microscope appeared as circular to spindle shape with no extended extension from the cell while the differentiated cell into motor neuron showed cell body contain dendrites and long extended axon ended with small dendrite under two thousand increase in size Figure (2) and (3).

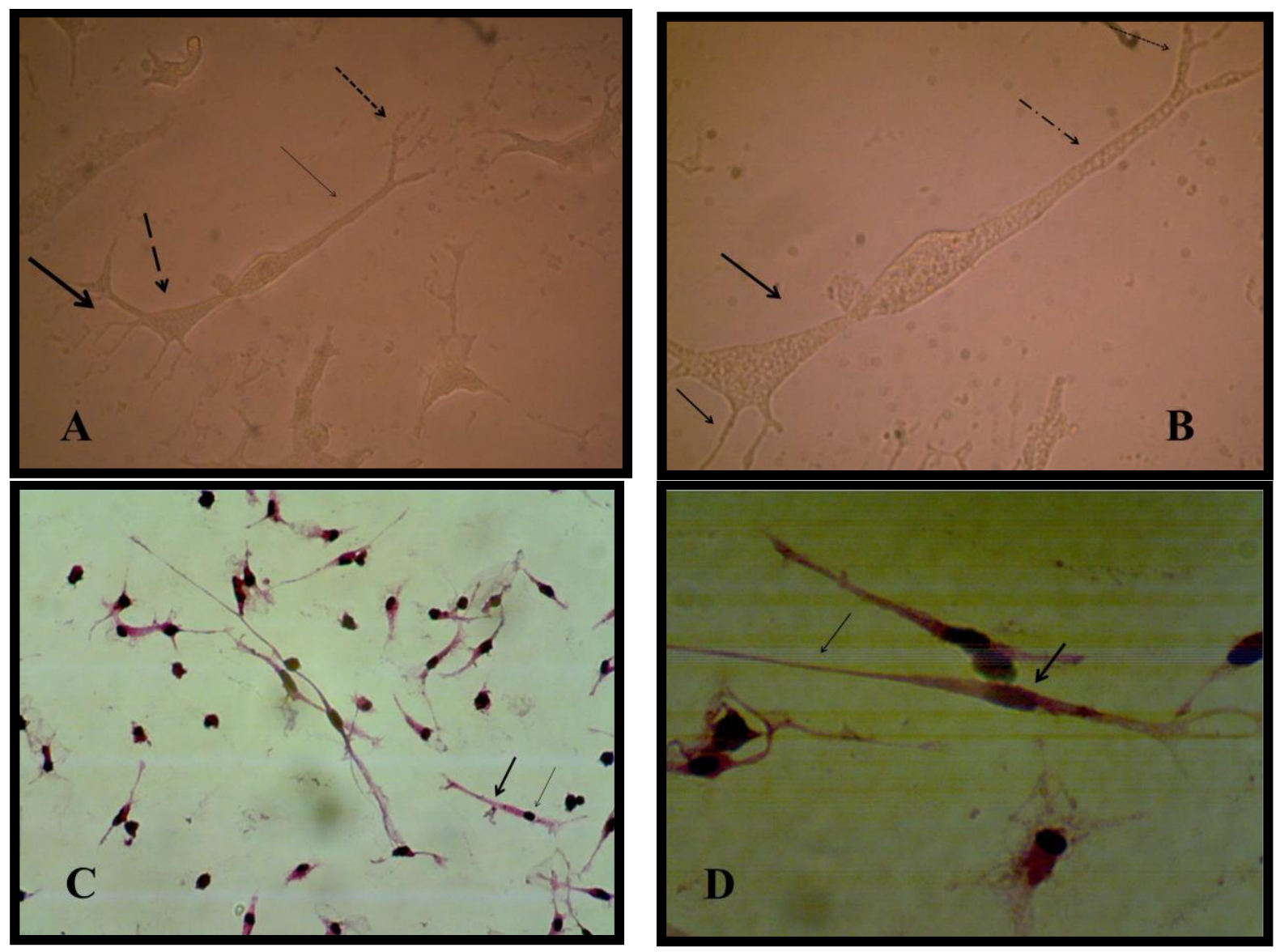

Figure2. Motor neuron cell $\mathbf{A}$ and $\mathbf{B}$ viewed (10X10)(10X20) under inverted microscope at the end of induction differentiation stage, cell body became like motor neuron cell soma have many dendrites and long axon like structure ended with small extensions., $\mathbf{C}$ and $\mathbf{D}$ Hematoxiline and Eosin stain of differentiated motor neuron cell showing red neuclease and blue cytoplasm (10X20)(10X100).
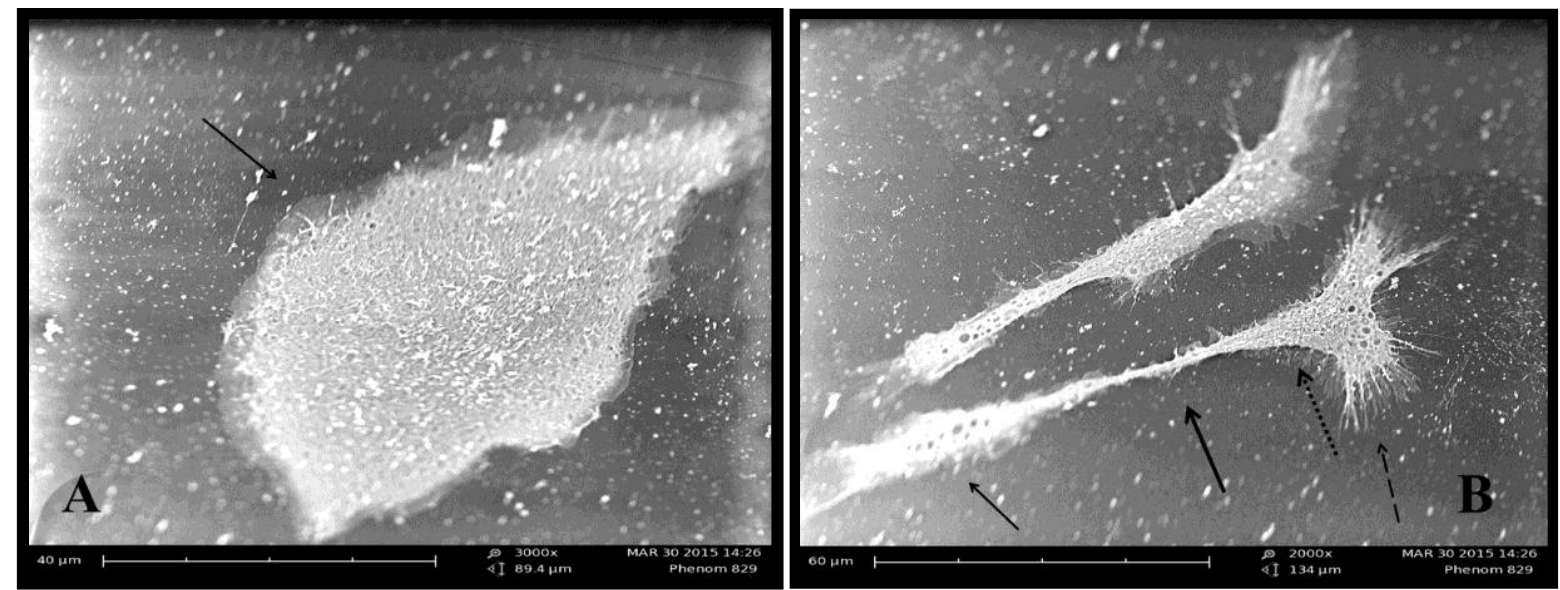

Figure3. A MSC using scanning electron microscope 3000 time increase in size showing dipolar structure of cell. B. Differentiated motor neuron under scanning electron microscope 2000 time increase in size cell soma appeared less in size with many dendrites and extended of cell axon.

\subsection{Motor Neuron Cell Detection using Immunocytochemistry}

Bone marrow mesenchymal stem cell differentiation into motor neuron cell was detected by immunocytochemistry study. Motor neuron cell are mature differentiated cell have microtubule associated protein 2 (MAP2) and cholinacetyltransferase (CHAT) as specific marker. Results revealed that $90 \%$ of differentiated motor neuron was positive for MAP2 and about $85 \%$ for CHAT Figure (4). 

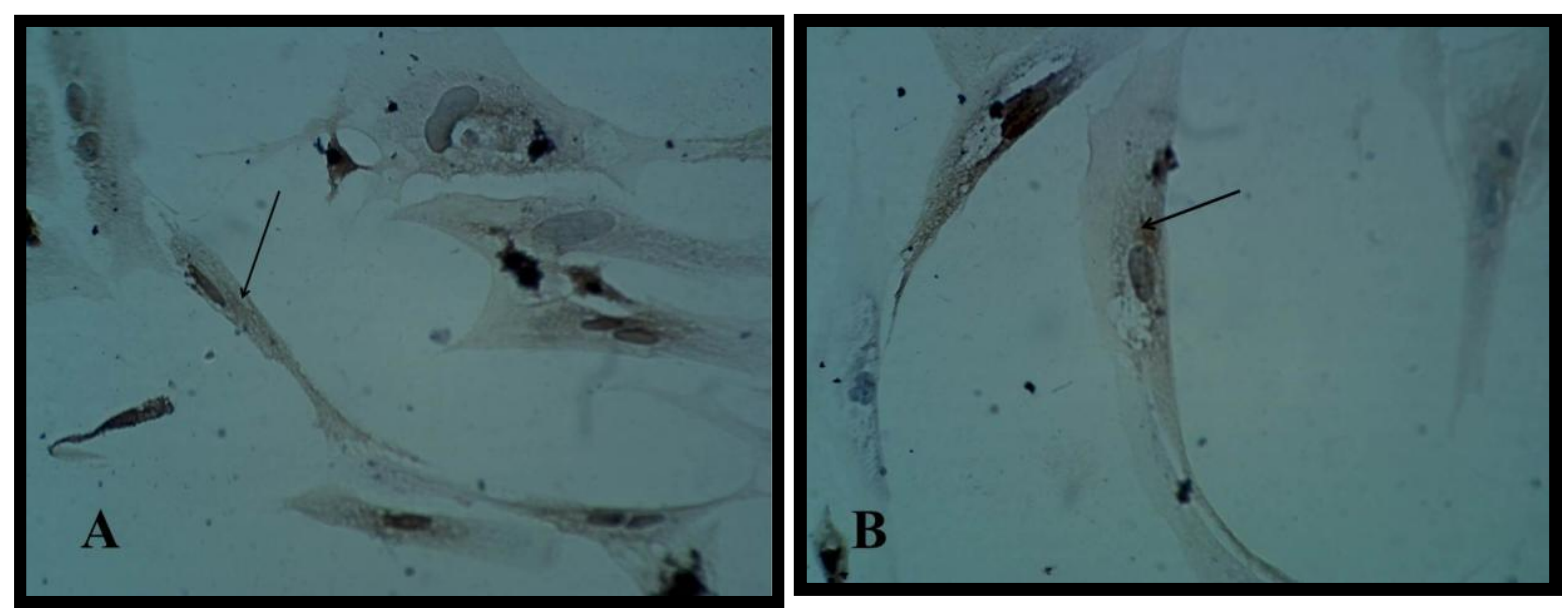

Figure4. A and $\mathbf{B}$ Immunocytochemical analysis for MAP-2 and CHAT in motor neuron after induction stage showed positive reactivity (brown color) (10X40).

\subsection{Motor Neuron Function Detection}

The activity of motor neuron by measuring the level of acetylcholine produced by differentiated cells in culture media. The increase level of neurotransmitter acetyl cholineproduced in culture media estimated functionality of motor neuron.

Results revealed that a significant increase $(75.0 \pm 0.57 \mathrm{pmm})$ in Acetyl CoA produced by motor neuron in differentiation medium at $4^{\text {th }}$ day after induction stage in comparison with zero day and after $24 \mathrm{~h}$ (15.43 \pm 0.38 and $15.36 \pm 0.44 \mathrm{pmm}$ ) Figure (5).

Motorneuron cell produce acetyl choline as cholinergic compound from choline and acetyl co A metabolized by enzyme Acetyl choline transferase which expressed strongly in differentiated cell immuonocytochemicaly by CHAT primary antibody as shown in figure (5), therefore acetylcholine present in media indicate that motoer neuron functionally active cell .

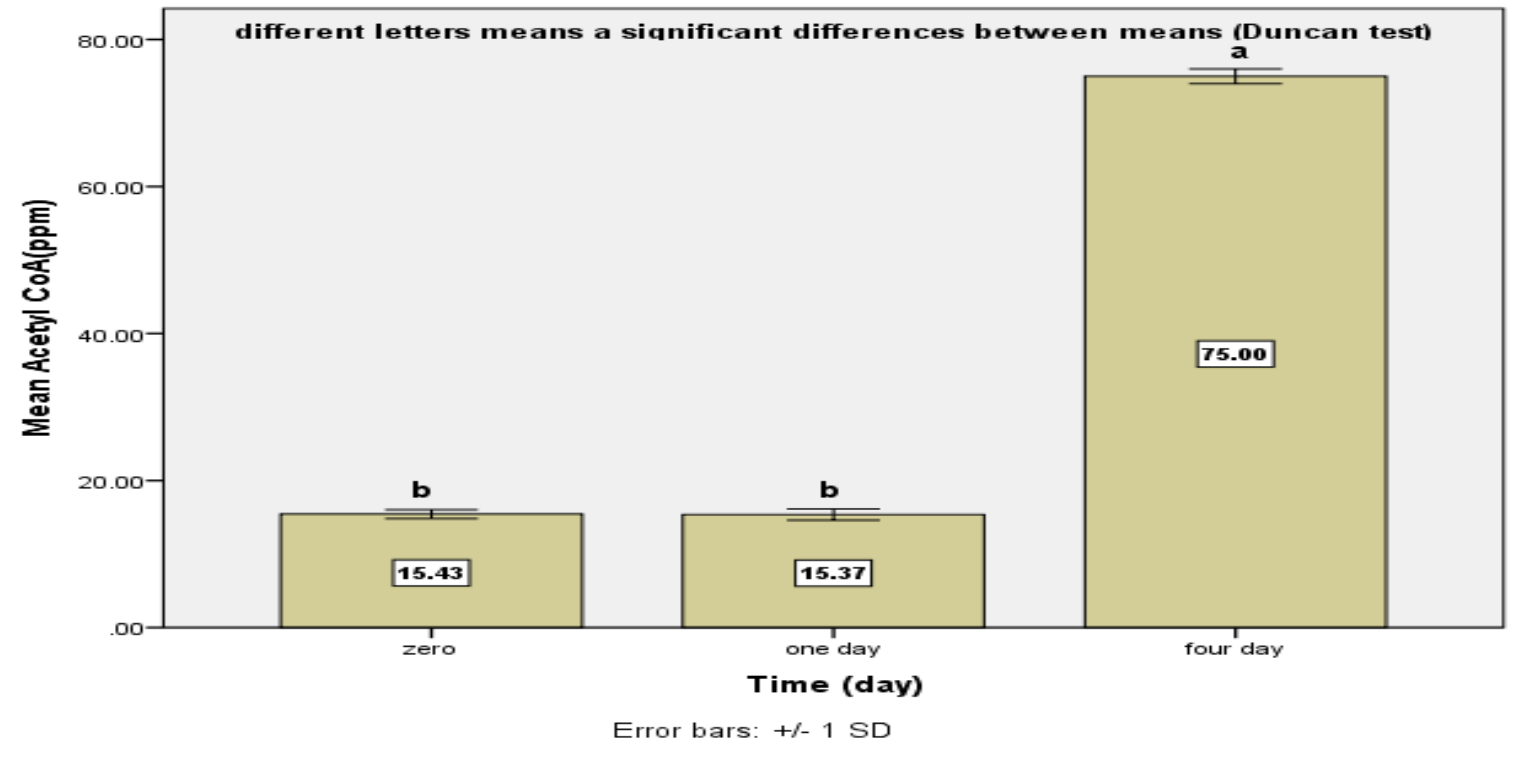

Figure5. Level of Acetyl Co A produced by motor neuron after different differentiation period.

\subsection{A Assay of Elongating Moto Neuron Cell Axon}

Results showed the highest elongation of motor neuron cell axon with a significant increase was (1.93 $\pm 0.185) \mathrm{mm}$ noticed at a concentration $160 \mathrm{ng} /$ when a nerve growth factor was added to motor neuron differentiation media in the induction stage in addition to RA and SHH compared with control Figure (9-3 A) . Results showed a significant increase in axon length was observed $(0.833 \pm 0.145$, $0.86 \pm 0.145,1.3 \pm 0.10$ and $1.76 \pm 0.317$ vs $0.433 \pm 0.145) \mathrm{mm}$ respectively in comparison with control when serial concentrations of NGF added to culture media (10,20, 40 and 80) $\mathrm{ng} / \mathrm{ml}$ respectively Figure(9-3) and (10-3). This indicates that NGF induced axon elongation when added to the 


\section{Induction of Bone Marrow Adult Mesenchymal Stem Cells into Functional Motor Neuron}

differentiation culture media into motor neuron cell. Nerve growth factor have an elongation capability for motor neuron cell axon with increasing concentration represent a promising tools for producing spinal cord motor neuron cell with long axon.

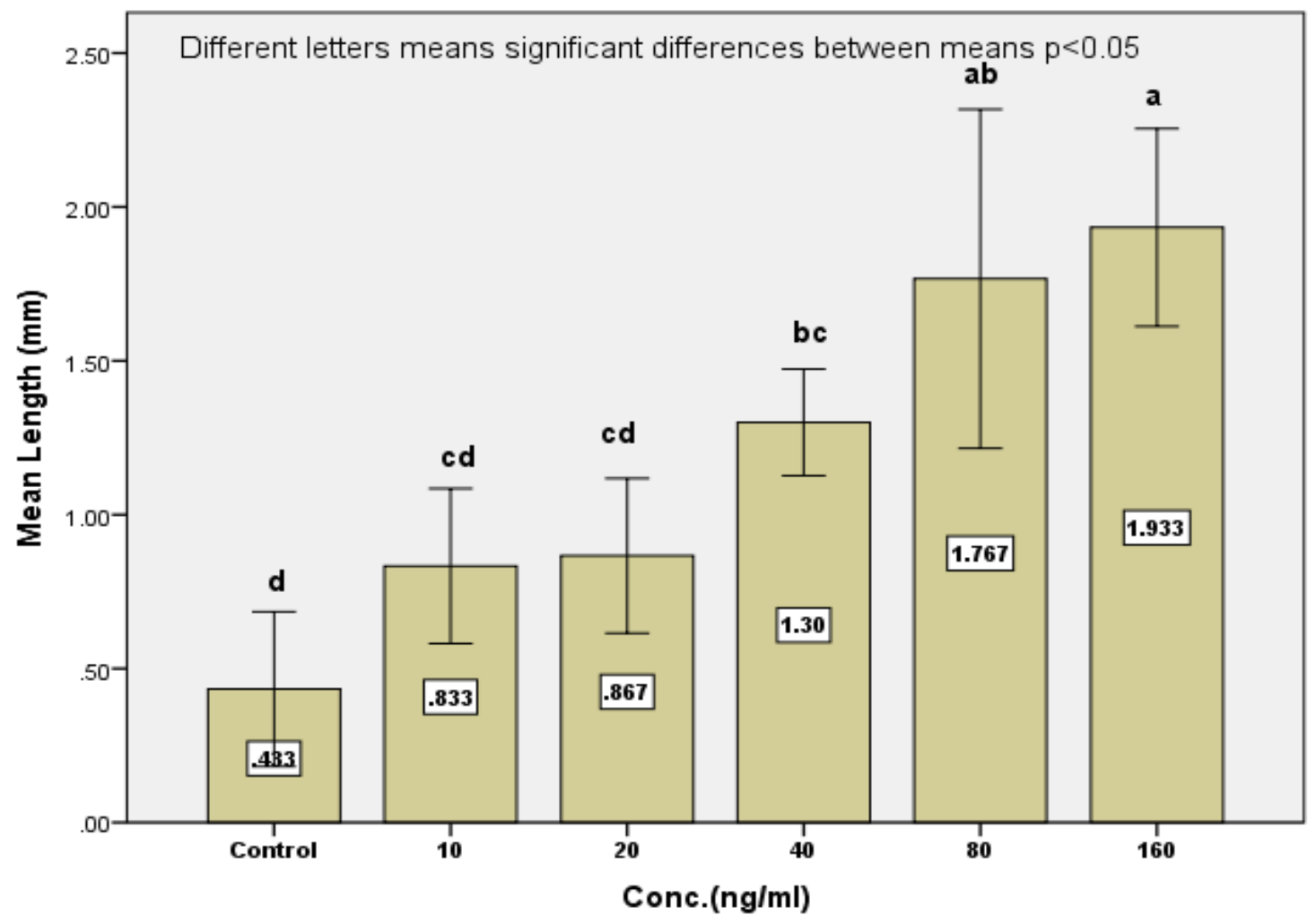

Error bars: +/- $1 \mathrm{SD}$

Figure1. Axon length after addition different concentrations of nerve growth factor in differentiation media
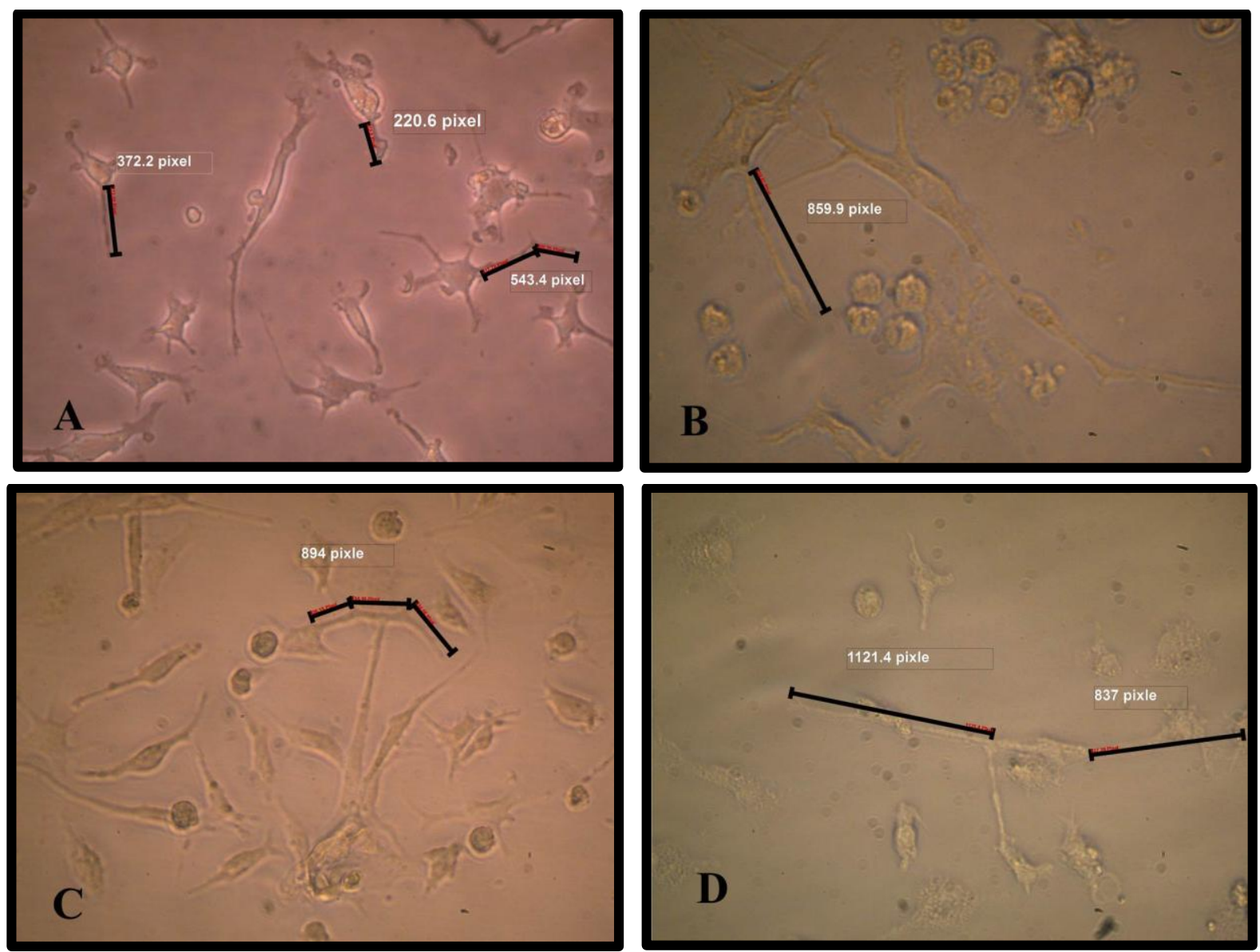
Rafal H. Abdullah et al.

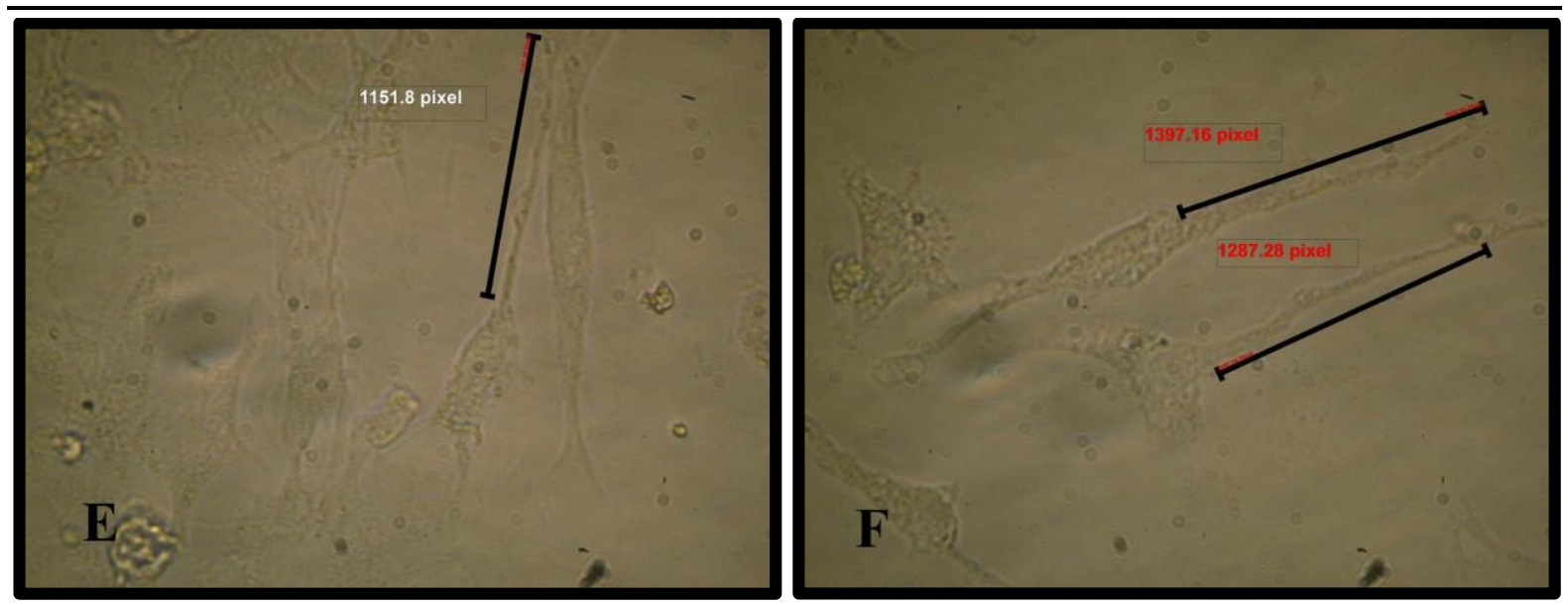

Figure2. A Motor neuron cell without NGF. B, C ,D, E and $\mathbf{F}$ motor neuron cell with different concentration of NGF 10, 20, 40, 80 and $160 \mathrm{ng} / \mathrm{ml}$ added to culture media, an increase in axon length was noticed.

\subsection{Differentiation of Mesenchymal Stem Cell in Three Dimensional Cultures}

Neutralized collagen matrix in 8well tissue culture slide had a smooth surface area as shown in (A and B) Figure (4) then mouse bone marrow MSCs cultured on the surface of matrix using the previous differentiation media for the same period of time successfully to mimic in vivo structure of brain and spinal code tissue. The cell and matrix after fixation and staining showed like thin lens layer as shown in in Figure (4).

Mesenchymal stem cells in collagen matrix in $\mathrm{CO} 2$ incubator showed either spindle shape with two or three polar cytoplasmic processes and extended within matrix or semicircular structure on threedimensional culture conditions and accumulated together on matrix and some are overlaped Figure(4)
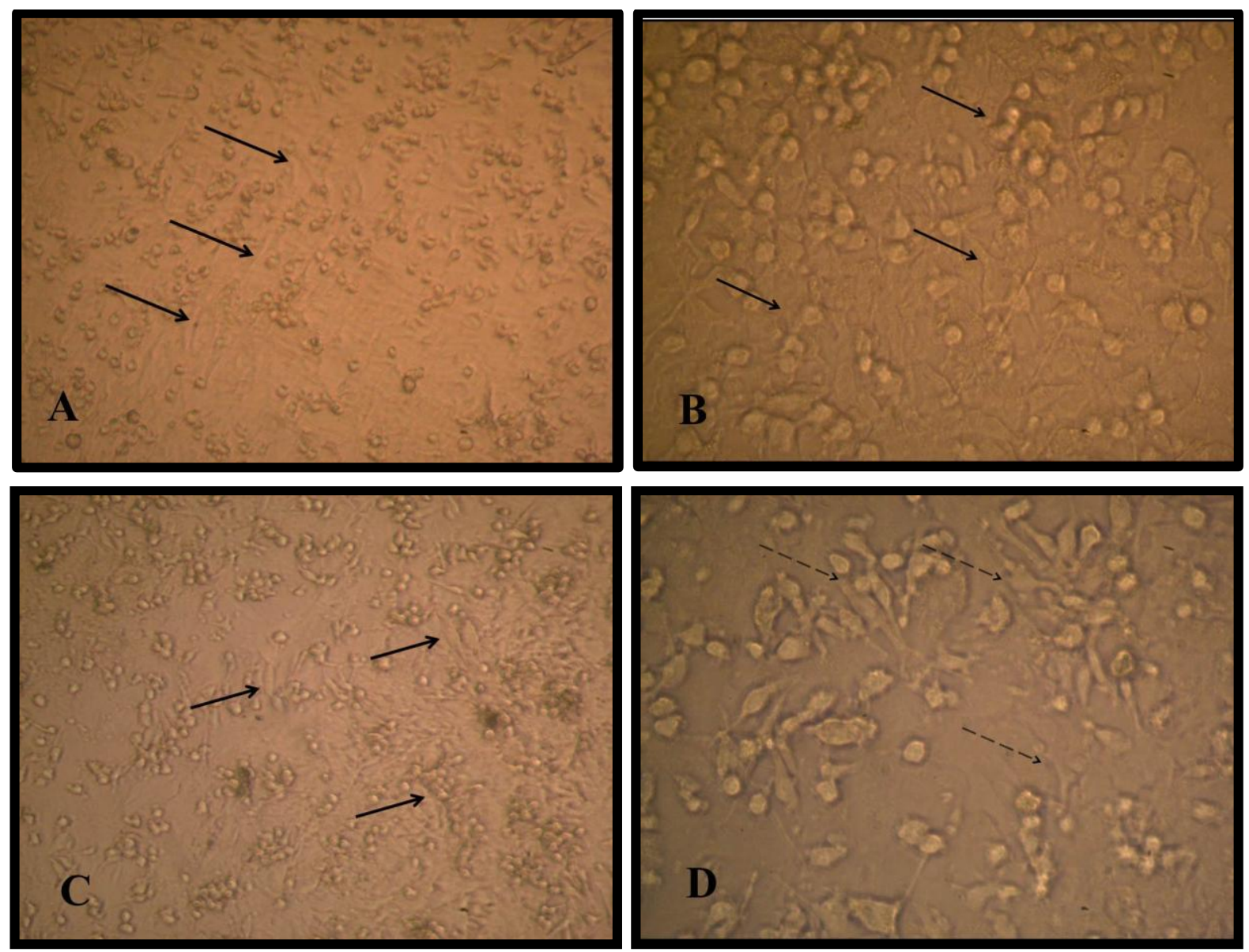

Figure4. A and B BM-MSCs cultured on collagen matrix after $24 \mathrm{~h}$ under inverted microscope (10X10)(10X20). C and $\mathbf{D}$ cultured on collagen matrix after 48 h under inverted microscope (10X10)(10X20). 


\section{Induction of Bone Marrow Adult Mesenchymal Stem Cells into Functional Motor Neuron}

The pre induction stage of differentiation of MSCs into motor neuron cell on collagen matrix in $\mathrm{CO} 2$ incubator showed that the cells became penetrating in matrix and had more cytoplasmic extend forming neural like structure.

At the end of the induction stage the cell had big soma structure contain many extensions of dendrites and in the other side long extended axis like axon ended with small dendrites like in structure the motor neuron cell Figure (5).

Stem cells differentiated on Hydrogel with culture media contain $1 \mu \mathrm{M}$ RA added regulated formation of neural and astrocyte lineages and when RA and Shh were added to the culture, either alone or together, 3D collagen-1 scaffolds enhanced significant motor neuron formation, while 3D matrigel stimulated dopaminergic neuron differentiation.
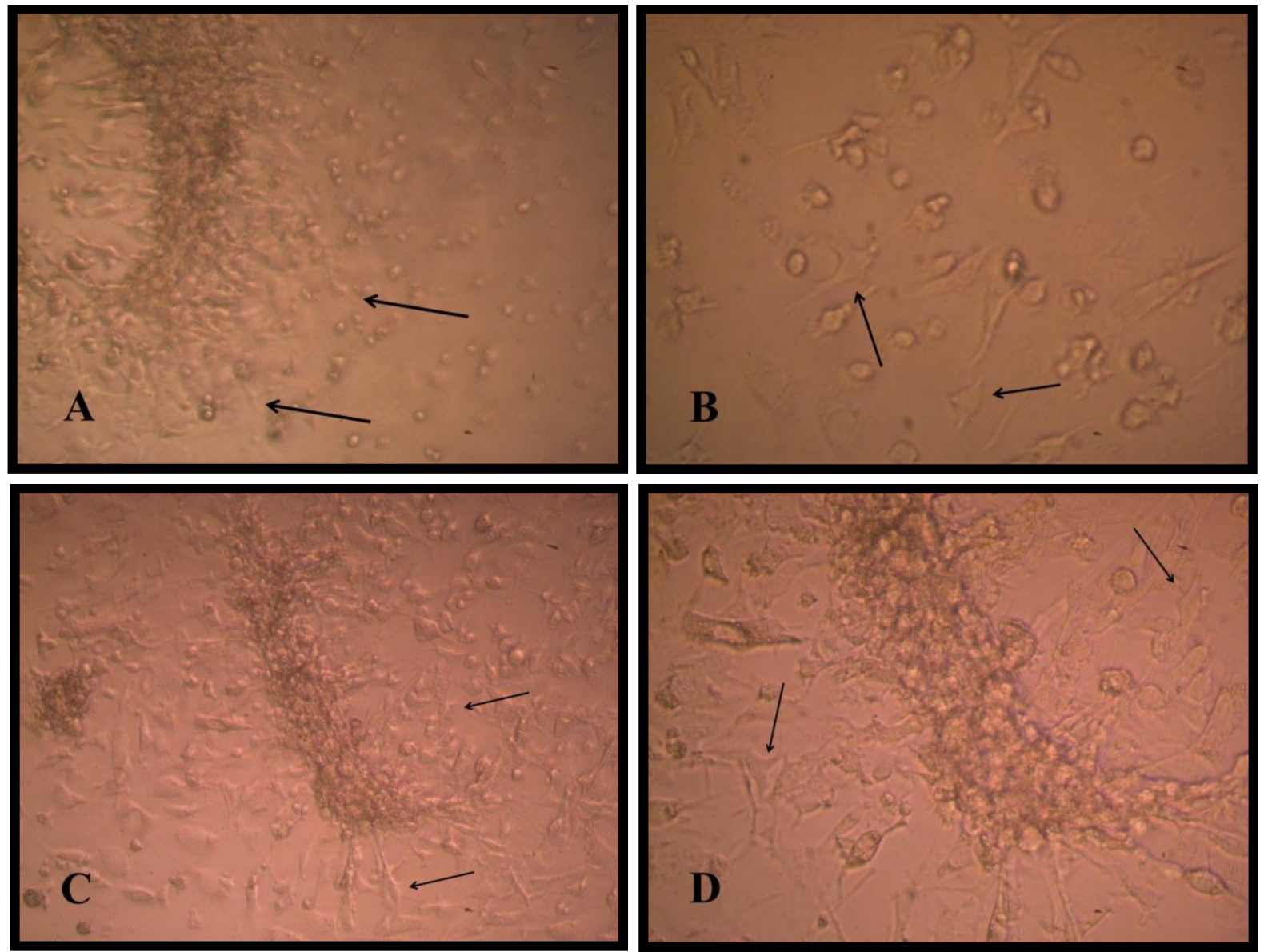

Figure5. $\boldsymbol{A}$ and $\boldsymbol{B}$ BM-MSC cultured on collagen matrix in pre induction stage in $1 \mathrm{mM}$ BME for $24 \mathrm{~h}$ under inverted microscope (10X10)(10X20). $\boldsymbol{C}$ and $\boldsymbol{D}$ cultured on collagen matrix in pre induction stage after $1 \mathrm{~h} 2.5$ mM BME under inverted microscope (10X10)(10X20).

Results revealed that differentiated motor neuron on collagen were positive for MAP2 and for CHAT Figure (5)
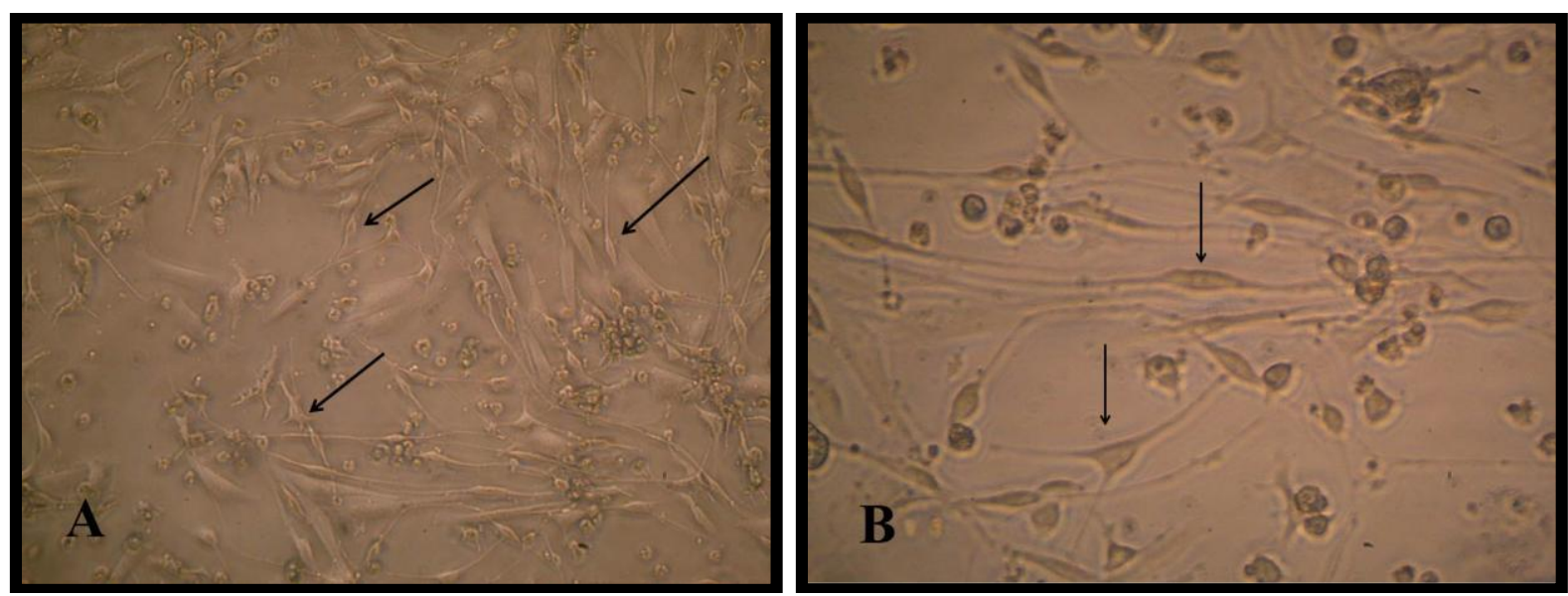


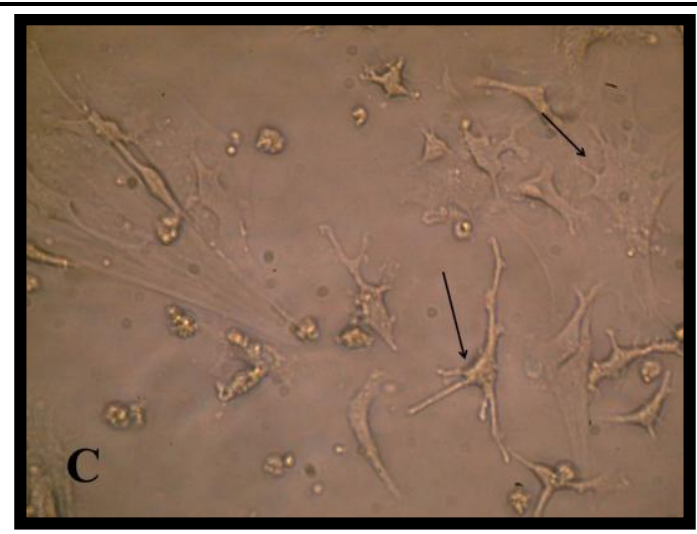

Figure6. A. Differentiated motor neuron cell on collagen matrix showing cell on the surface and other inserted into the collagen under inverted microscope (10X10) B. under inverted microscope (10X20) the neural cell structure appears clearly and other long extended cell. C. Motoe neuron cell differentiated on collagen matrix, small dendritic soma with long extended axon (10X20).
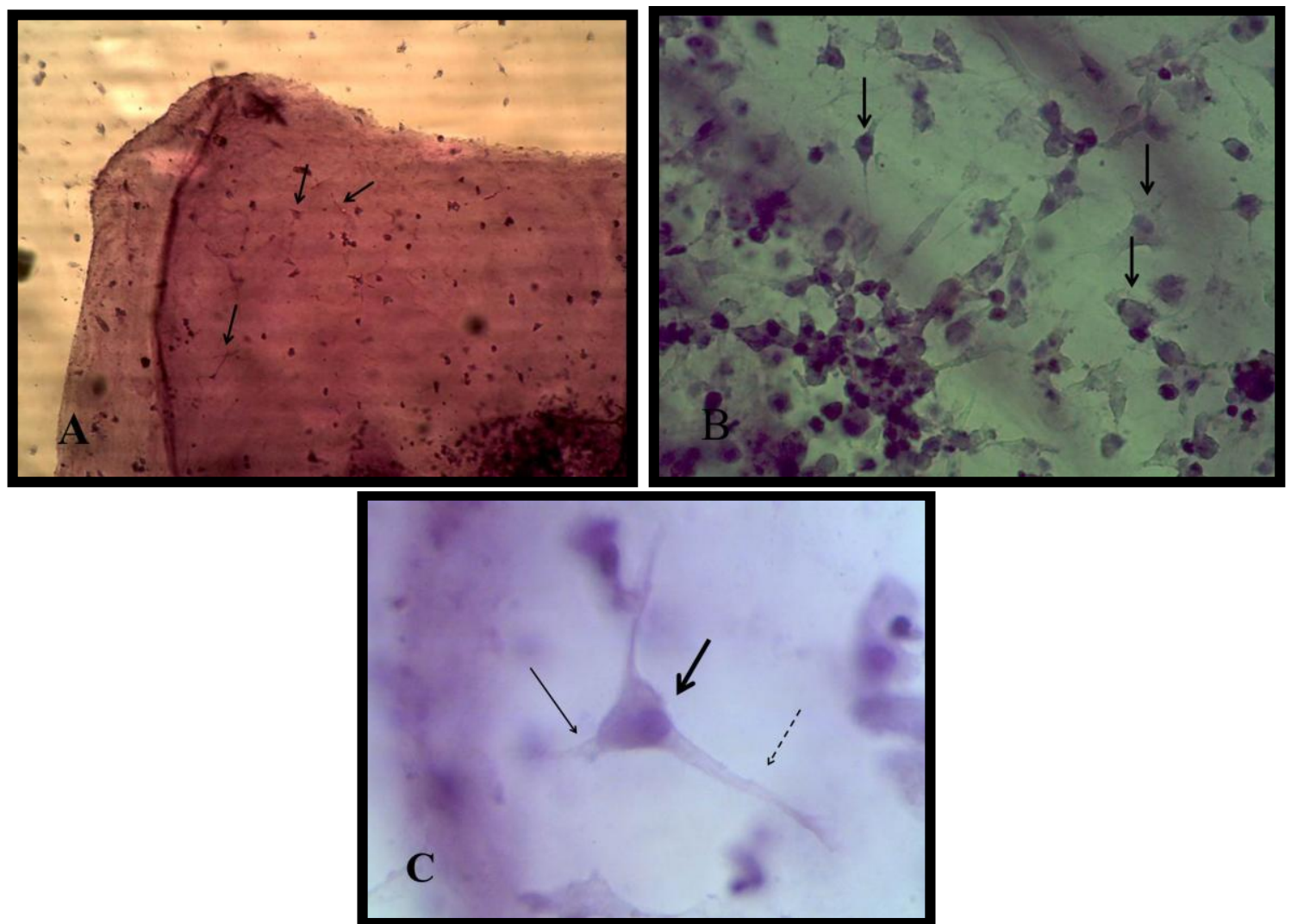

Figure7. A .Collagen matrix layer contain motor neuron cell differentiated on its surface at (10X10). B. motor neuron cells diferentiated into motor neuron showing cell structure on matrix (10X40). C. motor neuron cell differentiated on matrix surface stained with $H$ and $E$ under the microscope. (10X100).

Motor neuron cells differentiated from MSC in this study showed positive results for the differentiation marker MAP-2 and CHAT when detected immuonocytochemicaly on the surface of the matrix, Figure (8).
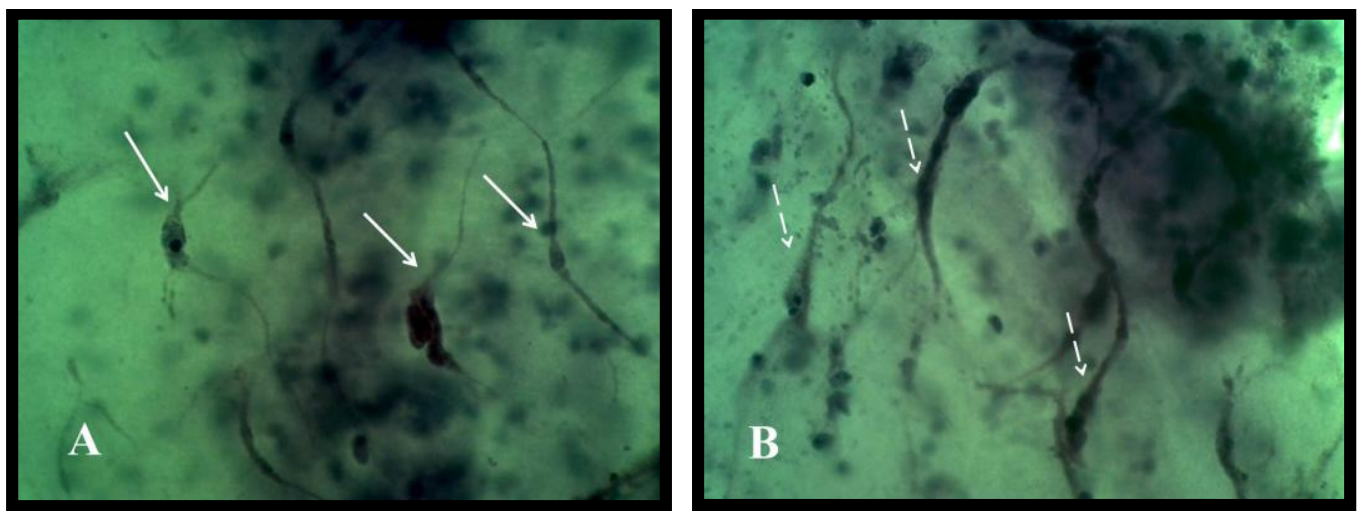


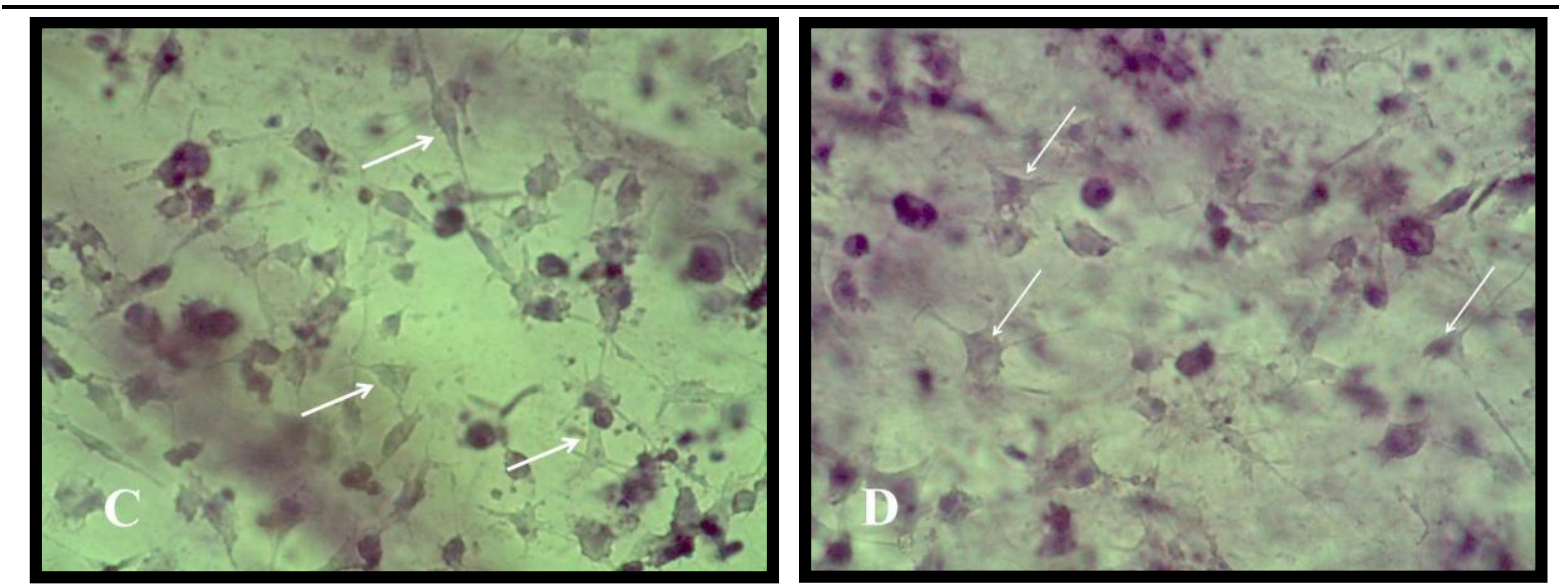

Figure8. A. and C. Immuonocytochemistry study of motor neuron differentiated cell on the surface of collager matrix for MAP-2 B.and $\mathbf{D}$ immuonocytochemistry study of motor neuron differentiated cell on the sufrace of collager matrix for CHAT.

\section{DisCUSSION}

\subsection{Motor Neuron Induction}

Scientists works on bone marrow culture in $1 \mathrm{mM}$ BME showed that cell cytoplasm retract and when exposed to 5mM BME for 6 hours, the cell had multipolar body structure (liu,et al., 2011) and also cells incubated in BME for few hours were elongated and beard process like extensions and were immunoactive for neuron specific enolase, nestin, glial fibrillaey acidic protein (Mareschiet al, 2006) and this is as well showed in the results and picture .

The first and second stages of induction represent the most effective, efficient and shortest induction time method for differentiation of mouse bone marrow MSC into motor neuron cells in compare with Shetty and his workers (2015) whose cultured cells in complicated culture media as pre induction, induction in RA and forskolin for $24 \mathrm{~h}$ and finally 6-8 days in RA and SHH but they started culturing forming neurospher from MSC on unattached surface flask.

Other workers induce differentiation of MSCs into MNCs for longer time up to two weeks using large amount of growth factor and specific culture conditions like neural body induction and then differentiation (Ebrahimin- Barough, et al .2014).

\subsection{Motor Neuron Cell Detection using Immunocytochemistry}

Differentiation indication markers MAP-2 used in this study and the results proved that mature spinal cord neuron, MAP-2 a cytoskeletal protein, present in the axon and dendrite of the cell body reveled by mRNA in situ hybridization (Hirokawaet al., 1996).

$\mathrm{Bi}$, et al.(2010). found that the cells have three neural related marker expression increased nestin, NES and MAP-2 with increasing concentration of Retinoic acid by Real time PCR, these factor determined the differentiation into neuron.

The other marker improved the differentiation into motor neuron cells is acetyle choline transferase (CHAT), the enzyme responsible for biosynthesis of acetylcholine and present in the functional cholinergic neurons of the central and peripheral nervous system indicate motor neuron cell (Oda ,1999) and also other studies on embryonic stem cell differentiation into motor neuron using sequence of culturing procedures detected immunocytochemistry using Quantification of HB9 and CHAT cells showed just 30\% of total cell are mature motor neuron(Hester, 2011).

\subsection{Motor Neuron Function Detection}

Liu, et al. (2013) showed the production and secretion of acetylcholine from motor neuron cell derived umbilical cord mesenchymal stem cell, positive for acetylcholine transfarase, increased during the period of differentiation from very little in the $9^{\text {th }}$ day of 15 differentiation day, about $2.8 \mathrm{ng} / \mathrm{ml}$ to $5.7 \mathrm{ng} / \mathrm{ml}$ at the end of differentiation using heparin end fibroblast growth factor comparing with mesenchymal stem cell control which not produce any acetylcholine .

Murine and human embryonic stem cell synthesize acetyl choline and express acetyl choline transferase in regulation of embryonic stem cell as calcium dynamics, cell survival and proliferation, 
it's increased the viability, but decreased the proliferation of embryonic stem cells this indicate the presence of low concentration of acetylcholine in the culture of MSCs and pre induction stage of differentiation (Landgrafet .al,2010; Takahashi ,2015)

\subsection{Assay of Elongating Moto Neuron Cell Axon}

Lentz et al. (1999) studied the effect of NGF on the sensory nerve cell axon during the even embryogenesis and showed that different concentration of NGF had different effect on the length of axon in which culture without NGF produce cell with small extended axon. Also a significant increase in axon length were shown in study of Martin et al., (2002) on olfactory neuron axon when $50 \mathrm{ng} / \mathrm{ml}$ of NGF added to culture of cells. One of GTP-superfamily binding protein is inactivating by NGF through prevention of axon extension via the actin cytoskeletal so that differentiation culture media contain NGF increase the axon length (Stocum, 2012).

\subsection{Differentiation of Mesenchymal Stem Cell in Three Dimensional Cultures}

This phenomena showed also in other study of MSCs on collagen gel matrix containing fibronectin. Cells were adjacent in many parts, in direct contact and lined up in a row while and in 3D collagenlaminin gel, cells exhibited a highly elongated star shape and three-dimensional cultured cells appeared to present directional growth, a form of neuritis outgrowth found in neuronal cells (Lee, et al., 2011).

Culturing cells by Artym and Matsumoto (2011) insidethree-dimensional (3D) collagen matrices indicated the increasingly popular and enlarge the understanding of cellular processes and cell - ECM interaction.

These indicate that synergistic role of micro environmental cues ESC differentiation and maturation, with potential applications in cell transplantation therapy (Kothapalli and Kamm, 2013).

Other scientific work on MSCs cultured on extracellular matrix and Matrigel immobilize gell showed greater differentiation into neural cells than 2D culture indicating aspecial interaction between cell and extracelullar matrix. Also cells cultured on extracellular-grafted showed higher neural differentiation ratios than those on extracellular 2Dculture this strenght the resulted cells after differentiation with motor neuron structure (Higuchi,et al,2011).

Human embryonic stem cells hEnSCs differentiation into motor neuron using in (polylactic-coglycolic acid) PLGA showed that PLGA scaffolds enhances more the differentiation of hEnSCs into motor neuron-like cells in comparison with tissue culture plats. So PLGA nanofibers provide a suitable topography for motor neuron differentiation of hEnSCs. The expression of Islet-1 (80\%), Chat $(89 \%)$, NF-H (50\%), and beta-tubulin III (40\%) in PLGA group were higher than the expression of Islet-1 (70 \%), Chat (79 \%), NF-H (40\%), and beta-tubulin III (40\%) in tissue culture plats (Ebrahimi-Baroughet al.,2014) .

\section{Conclusion}

Mesenchymal stem cell represent agood source for differentiation into functional motor neuron using less growth factor and time as differentiation of embryonic stem cell and elongation of motor neuron cell axon for future using in spinal cord repair. Collagen matrix represents a benefit structure for miming the normal tissue structure for differentiation of MSC to motor neuron.

\subsection{Glossary}

Mesenchymal stem cell have retracted capacity of differentiation towered few lineage of cell differentiated mainly from mesoderm embryonic germ layer give rise to skeletal and connective tissue.

MotorneuronMotor neurons are specialized nerve cells in the brain and spinal cord that transmit the electrical signals to muscle and generate movement.

Axon elongation an increasing cell axon that extends from the cell body using special growth factor.

Collagen matrix supportive structures that induce cells to form functional tissues, is one of the main object of tissue engineering and regenerative medicine research.

\section{ACKNOWLEDGMENT}

I would like to express thanks to the ICCMGR and every single staff member in it, thank you for helping, supporting and kindness. 


\section{REFERENCES}

Artym, V. and Matsumoto, K. (2011). Imaging Cells in Three-Dimensional Collagen Matrix .Current Protocol of Cellular Biology. National Institution of Health .10:1820:1-23.

Bi,Y.; Gong,M.; Zhang,X.; Zhang,X.; Jiang,W.; Zhang,Y.; Chen,J.; Liu,Y.; He,T.andLi,T.(2010). Pre-activation of retinoid signaling facilitates neuronal differentiation of mesenchymal stem cells. Development, Growth and Differentiation. 52: 419-431.

Colombo,J.; Almeida,J. and Molina,S. (1987).In vitro culture and labeling of neural cell aggregates followed by transplantation. Experimental Neurology.98(3): 606-615.

Cregg ,J.; Wiseman ,S.; Pietrzak - Goetze ,N.; Smith,M.; Jaroch,D.; Clupper,D. and Gilbert, R.(2010). Arapid, quantitative method for assassing axonal extention on biomaterial platforms. Tissue Engineering , Mary Ann Liebert, Inc .16:167-172.

Ebrahimi-Barough, S. ; Javidan ,A.; Saberi ,H; Joghataei,M. ; Rahbarghazi ,R.; Mirzaei,E. ; Faghihi ,F.; Shirian ,S.; Ai, A. and Ai, J. (2014). Evaluation of Motor Neuron-Like Cell Differentiation of hEnSCs on Biodegradable PLGA Nano fiber Scaffolds. Molecular Neurology.1:10-14.

Ebrahimi-Barough, S. ; Javidan ,A.; Saberi ,H; Joghataei,M. ; Rahbarghazi ,R.; Mirzaei,E. ; Faghihi ,F.; Shirian ,S.; Ai, A. and Ai, J. (2014). Evaluation of Motor Neuron-Like Cell Differentiation of hEnSCs on Biodegradable PLGA Nano fiber Scaffolds. Molecular Neurology.1:10-14.

Guo,L.; Yin ,F.; Meng ,H.;Ling ,L.; Hu-He, T.; Li,P.; Zhang,C.;Yu, S.;Duan,D. (2005) . Differentiation of Mesenchymal Stem Cells Into Dopaminergic Neuron-like Cells in vitro 'Biomedical and Environment Sciences. 18: 36-42.

Hester,M.;Murtha1,M.; Song,S.; Rao,M.; Miranda,C.; Meyer,K.; Tian,J.; Boulting , G.; Schaffer,D.; Zhu,M.;Pfaff,S.; Gage,F. and Kaspar,B.2011.Rapid and Efficient Generation of Functional Motor Neurons From Human Pluripotent Stem Cells Using Gene Delivered Transcription Factor Codes.Molecular Therapy. 19:10:1905-1912.

Higuchi1,A.; Huang,S.; Shen,P.; Ling,Q.; Zhao,J.; Chang,Y.; Wang,H. Bing,J. and Hsu,S. (2011). Differentiation abiltity of amoniaticfluidderived stem cells cultured on etracelullar matrix immobilized surface. Current Nanoscience. 7: 893-901.

Hirokawa,N.; Funakoshi,T.; Sato-Harada,R. and Kanai,Y.1996. Selective Stabilization of Tau in Axons and Microtubule-associated Protein $2 \mathrm{C}$ in Cell Bodies and Dendrites Contributes to Polarized Localization of Cytoskel et al Proteins in Mature Neurons. The Journal of Cell Biology. 132:4:667-679.

Hu, B. and Zhang, S. (2009). Differentiation of spinal moto neurons from pluripotent human stem cell. Natural protocol .4(9):1295-1304.

$\mathrm{Hu}$, B. and Zhang, S. (2009). Differentiation of spinal moto neurons from pluripotent human stem cell. Natural protocol .4(9):1295-1304.

Julio,C.;Tator,F. and Tator,C.H.(2012).global epidemiology of traumatic spinal cord injury .traumatic Brain and Spinal Cord Injury, ed. Cristina Morganti-Kossmann,Rafgupathi and Andrew MaasCambridge university press..

Kim,E .; Lee,K.; Yu,J.; Lee ,J.; Kim,K.; Han,K.; Park „K.; Lee,D. Kim,M. (2013). Neuronal cell differentiation of mesenchymal stem cells originating from canine amniotic fluid. Human Cell. 27:51-58.

Kothapalli ,C. and Kamm R. (2013). 3D matrix microenvironment for targeted differentiation of embryonic stem cells into neural and glial lineages.Biomaterials.34(25):5995-6007.

Kupiec, T. (2004).Quality control analytical methods: High performance liquid chromatography. International Journal of Pharmaceutical Compounding .8(3):223-227.

Landgraf ,D.; Barth, M.; Layer, P. and Sperling , L.(2010). Acetylcholine as a possible signaling molecule in embryonic stem cells: Studies on survival, proliferation and death. ChemicoBiological Interactions . 187:115-119.

Lee,J.; Yu, H.; Lee, G.; Hyun, A. and Kim,K.(2011). Collagen gel three-dimensional matrices combined with adhesive proteins stimulate neuronal differentiation of mesenchymal stem cells. J of Royal Society Interface.8:60.

Langer, R. and Vacanti, J.(1993). “Tissue engineering,”.Science. 260( 5110): 920-926. 
Lentz, S.; Knudson, C.; Korsmeyer, S. and Snider, W.(1999). Neurotrophins Support the Development of Diverse Sensory Axon Morphologies. The J of Neuroscie. 19(3):1038-1048.

Lin, C.; Xin, Z.; Dai,J.andLue,T.(2013). Commonly Used Mesenchymal Stem Cell Markers and Tracking Labels: Limitations and Challenges. Histopathology . 28(9): 1109-1116.

Liu, H. ;Xue, W.; Xie,Y.; Feng,X. and huo, F.(2011).Tea polyphenol induced neuron like differentiation of mouse mesenchymal stem cells. Chinese Journal of Physiology .54:(2):111117.

Liu, X.; Li,D.; Jiang,D. and Fang,Y.2013. Acetylcholine secretion by motor neuron-like cells from umbilical cord mesenchymal stem cells. Neural Regeneral Research. 8:22: 2086-2092.

Marani, E.; RuttenW.andDeenen,M.(2003). Neuronal Aggregates In Culture.Trakia Journal of Sciences.1( 3)23-25.

Mareschia ,K.;Novarab,M.; Rustichellia, D.; Ferreroa, I.; Guidob, D.; Carboneb,E.; Medicoc,E.; Madona,E.;Vercellid,A and Fagiolia.(2006). Neural differentiation of human mesenchymal stem cells: evidence for expression of neural markers and eag $\mathrm{K}+$ channel types. Experimental Hematology .34:1563-1572.

Mareschia „K.;Novarab,M.; Rustichellia, D.; Ferreroa, I.; Guidob, D.; Carboneb,E.; Medicoc,E.; Madona,E.;Vercellid,A and Fagiolia.(2006). Neural differentiation of human mesenchymal stem cells: evidence for expression of neural markers and eag $\mathrm{K}+$ channel types. Experimental Hematology .34 :1563-1572.

Martin ,L.; Weston, S.; West, A. and Chuah, M.(2002).Nerve growth factor promotes olfactory axonal elongation. Neuroreport. 13(5):621-625.

Moral-Sanz J; Lopez-Lopez, J.G.; Menendez ,C.; Moreno, E.; Barreira, B.; Morales-Cano, D.; Escolano, L.; Fernandez-Segoviano, P.; Villamor, E., Cogolludo,A.; Perez-Vizcaino, F.and Moreno, L.(2012). Different patterns of pulmonary vascular disease induced by type 1 diabetes and moderate hypoxia in rats.Exp Physiol. 97(5):676-86.

Oda,Y. (1999). Choline acetyl transferase: The structure, distribution and pathologic changes in the central nervous system. Pathology International . 49: 921-937.

Olsson- Carter,K. and Slack ,F.(2010).A developmental timing switch promotes Axon outgrowth independent of known guidance receptors . PLOS Genetics.6(8):1-11.

Purves, D.; Augustine, J.; Fitzpatrick, D.; Katz, L.; La Mantia, A.; Mc Namara, J. and Williams, M.(2001).Acetylcholine. Neuroscience. 2nd edition. Sunderland Sinauer Associates .

Qiang, L.; Yu, W.; Liu, M.; Solowska, J. and Baas, P. (2010). Basic fibroblast growth factor elicits forming of interstitial axonal branches via enhanced severing of microtubules. Molecular Biology of The Cell.21:334 - 344.

Ramírez, O. andCouve, A. (2011). The endoplasmic reticulum and protein trafficking in dendrites and axons. Trends in Cell Biology.21(4):219-227.

Ramírez, O. andCouve, A. (2011). The endoplasmic reticulum and protein trafficking in dendrites and axons. Trends in Cell Biology.21(4):219-227..

Saladin, K. (2004).The Spinal Cord, Spinal Nerves, and Somatic Reflexes. chapter 13. Anatomy \& Physiology: The Unity of Form and Function, ( $3^{\text {rd }}$ edition) . McGraw-Hill Higher Education Inc.

Scintu, F.; Reali, C. ;Pillai, R.; Badiali, M.; Sanna, M.; Argiolu, F.; Ristaldi, M. and Sogos, V.(2006).Differentiation of human bone marrow stem cells into cells with a neural phenotype: diverse effects of two specific treatments .BMC Neuroscience . 7: 14.

Shaham, S. (2005). Glia-Neuron Interactions in Nervous System Function and Development. Current Topics in Developmental Biology. 69:39-67.

Shetty ,P.;Pradhan ,S. and Viswanathan, C. (2015). A Highly Efficient Culture Technique for Derivation of Motor Neurons from Human Umbilical Cord Derived Mesenchymal Stem Cells. Journal of Neurology and Neurological Disorders. 1 (2):1-11.

Soleimani, M.and Nadri, S.(2009).A protocol for isolation and culture of mesenchymal stem cells from mouse bone marrow. Nature Protocols. 4: $102-106$.

Zeng, R.; Wang ,L.; Hu, Z.; Guo, W.; Wei, J.; Lin, H.; Sun, X.; Chen, L; Yang, L.(2011). Differentiation of human bone marrow mesenchymal stem cells into neuron-like cells in vitro.Spine (Phila Pa 1976). 36(13):997-1005. 
Trzaska, K.A.and Rameshwar, P. (2011). Dopaminergic neuronal differentiation protocol for human mesenchymal stem cells. MethodsMolecular Biology.698:295-303

Themistocleous, G.;Katopodis,H.; Sourla ,A.; Lembessis ,P.;Doillon ,C.; Soucacos , P. and Koutsilieris , M.(2004). Three-dimensional Type I Collagen Cell Culture Systems for the Study of Bone Pathophysiology. In vivo .18: 687-696

Talbot, K.and Marsden, R.(2008).Motor neuron disease . what is motor neuron disease . Oxford University Press Inc.USA

Takahashi , T.(2015).Non-neuronal functions of acetylcholine via muscarinic receptor subtypes: cellular proliferation and differentiation in mammals Neurotransmitter . 2: e499.1-3. 